\title{
A Ruthenium(II) Complex Stabilized by a Highly Fluorinated PCP Pincer Ligand
}

\author{
Marcella Gagliardo ${ }^{\dagger}$ Preston A. Chase,$^{\dagger}$ Martin Lutz,$‡$ Anthony L. Spek,, \\ Frantisek Hartl," Remco W. A. Havenith, ${ }^{\perp}$ Gerard P. M. van Klink, ${ }^{\dagger}$ and \\ Gerard van Koten*,†
}

\begin{abstract}
Debye Institute, Organic Chemistry and Catalysis, Padualaan 8, 3584 CH Utrecht, The Netherlands, Bijvoet Center for Biomolecular Research, Crystal and Structural Chemistry, Padualaan 8, 3584 CH Utrecht, The Netherlands, van't Hoff Institute for Molecular Sciences, Molecular Photonic Materials Group, University of Amsterdam, Nieuwe Achtergracht 166, 1018 WV Amsterdam, The Netherlands, and Debye Institute, Theoretical Chemistry Group, Padualaan 8, 3584 CH Utrecht, The Netherlands
\end{abstract}

Received May 27, 2005

\begin{abstract}
A novel $\mathrm{Ru}$ (II) complex containing an electron-poor, highly fluorinated $\mathrm{PCP}{ }^{\mathrm{ArF}}$ pincer ligand has been synthesized in good yield via a transcyclometalation reaction. The complex has been fully characterized by elemental analysis, 1D and 2D NMR techniques, UV-vis spectroscopy, and cyclic voltammetry. Single-crystal X-ray structural analysis and DFT calculations were performed. The structural features and electronic properties of the remarkably stable $\mathrm{PCP}^{\mathrm{ArF}}-\mathrm{Ru}$ (II) complex 4 have been investigated and show unanticipated differences compared to its protio analogue.
\end{abstract}

\section{Introduction}

Cyclometalated organometallic complexes containing monoanionic, potentially terdentate coordinating ECEpincer ligands $\left(\mathrm{E}=\mathrm{N}, \mathrm{P}, \mathrm{O}, \mathrm{S}\right.$; pincer $=\left[\mathrm{C}_{6} \mathrm{H}_{3}\left(\mathrm{CH}_{2} \mathrm{ER}_{x}\right)_{2}\right.$ $2,6]^{-}$) are widely applicable in such diverse fields as catalysis and mechanistic investigations, ${ }^{1}$ supramolecular chemistry, ${ }^{2}$ and sensor materials. ${ }^{3}$ Facile variation of the steric and electronic properties of the pincer ligand have allowed for the fine tuning of effects in the aforementioned applications. In particular, terdentate PCP pincer complexes of $\mathrm{Ru}, \mathrm{Rh}, \mathrm{Ir}, \mathrm{Ni}, \mathrm{Pd}$, and Pt have been used as efficient reagents and catalysts for a variety of organic transformations such as allylation of aldehydes, atom-transfer radical polymerization, dehydrogenation of alkanes, Heck olefin arylation, and Suzuki coupling of arylboronic acids with aryl bromide. ${ }^{1,4}$ With regard to $\mathrm{PCP}-\mathrm{Ru}$ (II) complexes, the majority of species reported to date contain phosphine donor atoms with electron-releasing alkyl or aryl sub-

* To whom correspondence should be addressed: E-mail: g.vankoten@chem.uu.nl.Fax:+31-30-252-3615. Tel: +31-30-253-3120.

Debye Institute, Organic Chemistry and Catalysis.

$¥$ Bijvoet Center for Biomolecular Research.

$\S$ To whom crystallographic inquiries may be directed. E-mail: a.l.spek@chem.uu.nl.

"University of Amsterdam.

${ }^{\perp}$ Debye Institute, Theoretical Chemistry Group (affiliated with Debye Institute, Organic Chemistry and Catalysis).

(1) Albrecht, M.; van Koten, G. Angew. Chem., Int. Ed. 2001, 41, 3750. (b) van der Boom, M. E.; Milstein, D. Chem. Rev. 2003, 103, 1759. (c) Singleton, J. T. Tetrahedron 2003, 59, 1837.

(2) Representative examples: (a) Sutter, J.-P.; Grove, M. D.; Beley, M.; Collin, J.-P.; Veldman, N.; Spek, A. L.; Sauvage, J.-P.; van Koten, G. Angew. Chem., Int. Ed. Engl. 1994, 33, 1282. (b) Omnes, L.; Timini, B. A.; Gelbrich, T.; Hursthouse, M. B.; Luckhurst, G. R.; Bruce, D. W. Chem. Commun. 2001, 2248. (c) Aiello, I.; Dattilo, D.; Ghedini, M.; Bruno, A.; Termine, R.; Golemme, A. Adv. Mater. 2002, 14, 1233.

(3) Albrecht, M.; Lutz, M.; Spek, A. L.; van Koten, G. Nature 2002 406,970 . stituents. ${ }^{5}$ As reported recently, $\mathrm{PCP}-\mathrm{Pd}$ (II) complexes with $\mathrm{P}\left(\mathrm{C}_{6} \mathrm{~F}_{5}\right)_{2}$ groups ${ }^{6}$ and $\mathrm{PCP}-\mathrm{Rh}(\mathrm{I})$ and $-\mathrm{Rh}(\mathrm{III})$ compounds ${ }^{7}$ containing $\mathrm{P}(\text { pyrrolyl })_{2}$ donors are the first examples where PCP complexes incorporate electronpoor, strong $\pi$-accepting phosphines. The altered electronics can have a profound impact on the molecular structure of the complexes and reactivity. As PCP-Ru(II) complexes are highly active catalysts in the transfer hydrogenation of ketones ${ }^{5 e, 8}$ and possess interesting redox and photophysical properties, ${ }^{9}$ the effects induced

(4) Representative examples: (a) Jensen, C. M. Chem. Commun 1999, 2443. (b) Liu, F.; Pak, E. B.; Singh, B.; Jensen, C. M.; Goldman, A. S. J. Am. Chem. Soc. 1999, 121, 4086. (c) Gibson, S.; Foster, D F.; Eastham, G. R.; Tooze, R. P.; Cole-Hamilton, D. J. Chem. Commun. 2001, 779. (d) Kanzelberger, M.; Zhang, X.; Emge, T. J.; Goldman, A. S.; Zhao, J.; Incarvito, C.; Hartwig, J. F. J. Am. Chem. Soc. 2003, 125, 13644. (e) Kjellgren, J.; Sundén, H.; Szabó, K. J. J. Am. Chem. Soc. 2004, 126, 474. (f) Wallner, O. A.; Szabó, K. J. Org. Lett. 2004, 6, 1831. (g) Göttker-Schnetmann, I.; White, P. S.; Brookhart, M. Organometallics 2004, 23, 1766. (h) Göttker-Schnetmann, I.; White, P. S. Brookhart, M. J. Am. Chem. Soc. 2004, 126, 1804. (i) Solin, N. Kjellgren, J.; Szabó, K. J. J. Am. Chem. Soc. 2004, 126, 7026. (j) Zhao, J.; Goldman, A. S.; Hartwig, J. F. Science 2005, 307, 1080. (k) Solin, N.; Wallner, O. A.; Szabó, K. J. Org. Lett. 2005, 6, 689. (1) Ray, A.; Zhu, K.; Kissin, Y. V.; Cherian, A. E.; Coates, G. W.; Goldman, A. S. Chem. Commun. 2005, 3388.

(5) (a) Karlen, T.; Dani, P.; Grove, D. M.; Steenwinkel, P.; van Koten, G. Organometallics 1996, 15, 5687. (b) Jia, G.; Lee, H. M.; Xia, H. P. Williams, I. D. Organometallics 1996, 15, 5453. (c) van der Boom, M. E.; Kraatz, H.-B.; Hassner, L.; Ben-David, Y.; Milstein, D. Organometallics 1999, 18, 3873. (d) Gusev, D. G.; Dolgushin, F. M.; Antipin, M. Y. Organometallics 2000, 19, 3429. (e) Amoroso, D.; Jabri, A.; Yap, G. P. A.; Gusev, D. G.; Dos Santos, E. N.; Fogg, D. E. Organometallics 2004, 23, 4047.

(6) Chase, P. A.; Gagliardo, M.; van Klink, G. P. M.; van Koten, G. Organometallics 2005, 24, 2016.

(7) Kossoy, E.; Iron, M. A.; Rybtchinski, B.; Ben-David, Y.; Shimon, L. J. W.; Konstantinovski, L.; Martin, J. M. L.; Milstein, D. Chem. Eur. J. 2005, 11, 2319

(8) (a) Dani, P.; Karlen, T.; Gossage, R. A.; Gladiali, S.; van Koten, G. Angew. Chem., Int. Ed. 2000, 39, 743. (b) Medici, S.; Gagliardo, M.; Williams, S. B.; Chase, P. A.; Gladiali, S.; Lutz, M.; Spek, A. L.; van Klink, G. P. M.; van Koten, G. Helv. Chim. Acta 2005, 88, 694.

(9) Gagliardo, M.; Dijkstra, H. P.; Coppo, P.; Lutz, M.; Spek, A. L.; van Klink, G. P. M.; van Koten, G. Organometallics 2004, 23, 5833. 


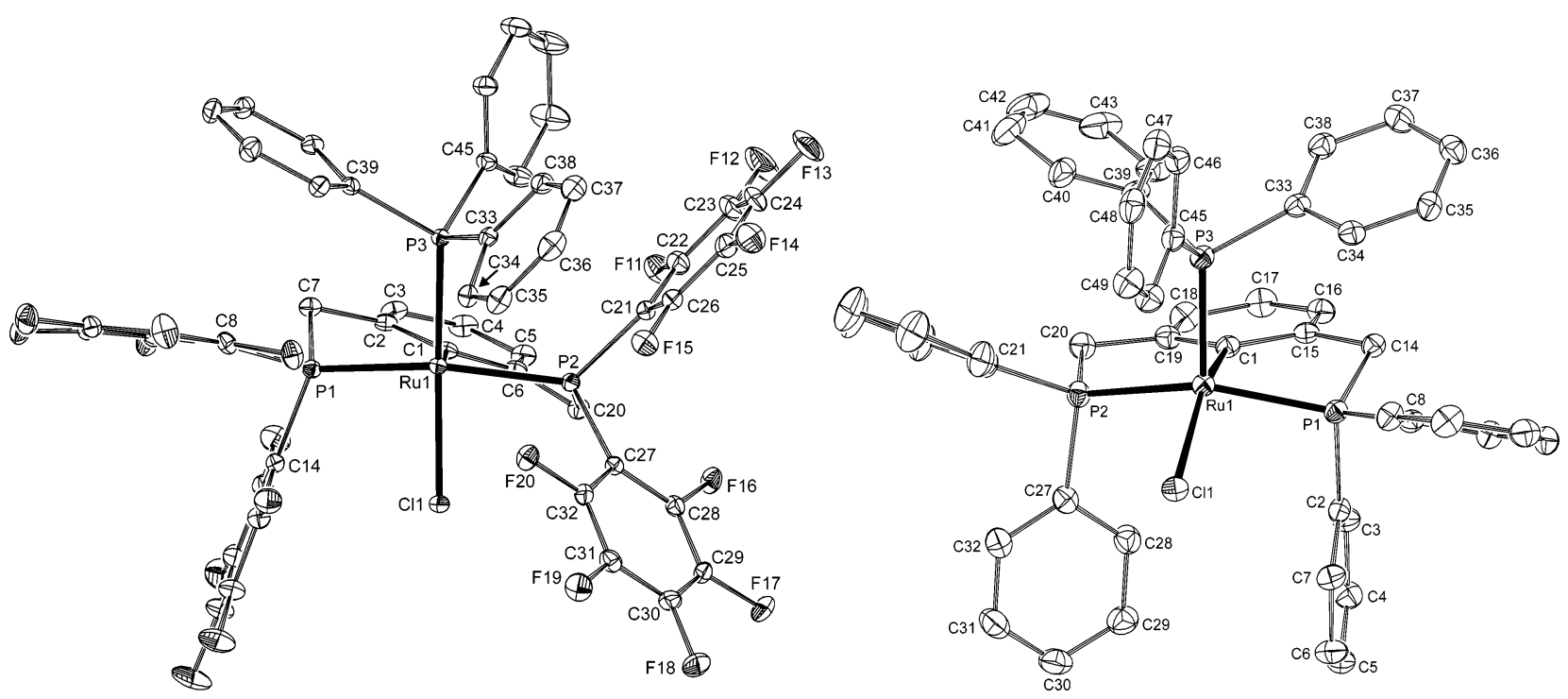

Figure 1. Molecular structures of 4 (left) and 5 (right) in the crystal state. Ellipsoids are drawn at the $30 \%$ probability level. Hydrogen atoms are omitted for clarity. Selected bond lengths $(\AA)$ and angles (deg) for 4: Ru1-C1 = 2.0330(17), $\mathrm{Ru} 1-\mathrm{P} 1=2.2905(5), \mathrm{Ru} 1-\mathrm{P} 2=2.3410(5), \mathrm{Ru} 1-\mathrm{P} 3=2.3154(4), \mathrm{Ru} 1-\mathrm{Cl} 1=2.4121(4), \mathrm{P} 1-\mathrm{C} 7=1.8275(18), \mathrm{P} 2-\mathrm{C} 20=$ $1.8322(18), \mathrm{P} 1-\mathrm{C} 8=1.8474(18), \mathrm{P} 1-\mathrm{C} 14=1.8531(18), \mathrm{P} 2-\mathrm{C} 21=1.8520(18), \mathrm{P} 2-\mathrm{C} 27=1.8468(18) ; \mathrm{P} 1-\mathrm{Ru} 1-\mathrm{P} 2=$ 159.006(17), Cl1-Ru1-P3 = 166.925(16), Cl1-Ru1-C1 = 96.46(5). Selected bond lengths (A) and angles (deg) for 5: Ru1$\mathrm{C} 1=2.073(3), \mathrm{Ru} 1-\mathrm{P} 1=2.3039(9), \mathrm{Ru} 1-\mathrm{P} 2=2.2937(9), \mathrm{Ru} 1-\mathrm{P} 3=2.2174(9), \mathrm{Ru} 1-\mathrm{Cl} 1=2.4797(8), \mathrm{P} 1-\mathrm{C} 2=1.838(3)$, $\mathrm{P} 1-\mathrm{C} 8=1.826(3), \mathrm{P} 2-\mathrm{C} 21=1.819(3), \mathrm{P} 2-\mathrm{C} 27=1.835(4) ; \mathrm{P} 1-\mathrm{Ru} 1-\mathrm{P} 2=151.21(3), \mathrm{Cl} 1-\mathrm{Ru} 1-\mathrm{P} 3=121.08(9), \mathrm{Cl} 1-$ $\mathrm{Ru} 1-\mathrm{C} 1=153.35(8)$.

\section{Scheme 1. Synthesis of $\left[\operatorname{RuCl}\left(\mathrm{PCP}^{\mathrm{ArF}}\right)\left(\mathrm{PPh}_{3}\right)\right](4)$ via a Transcyclometalation Reaction ${ }^{a}$}

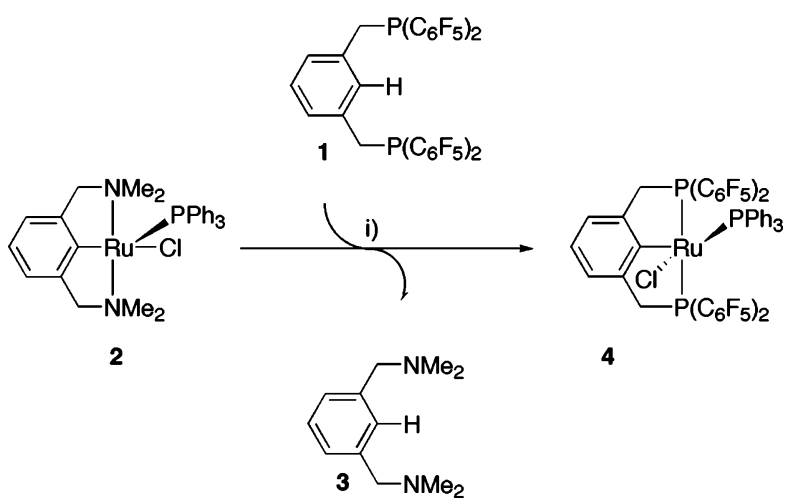

${ }^{a}$ Reaction conditions: (i) $\mathrm{C}_{6} \mathrm{H}_{6}$, reflux, $14 \mathrm{~h}$.

by incorporation of an electron-poor PCP ligand were investigated. Here, we report the synthesis, electronic properties, and unusual structure of the $\mathrm{PCP}-\mathrm{Ru}(\mathrm{II})$ complex 4 (Scheme 1) obtained from the highly fluorinated $\left[\mathrm{C}_{6} \mathrm{H}_{4}\left(\mathrm{CH}_{2} \mathrm{P}\left(\mathrm{C}_{6} \mathrm{~F}_{5}\right)_{2}\right)_{2}-1,3\right]^{5}$ (PCP ${ }^{\mathrm{ArF}}, \mathbf{1}$; Scheme 1) pincer ligand.

\section{Results and Discussion}

Direct cyclometalation ${ }^{5}$ of $\mathbf{1}$ with $\left[\mathrm{RuCl}_{2}\left(\mathrm{PPh}_{3}\right)_{3}\right]$, successfully applied previously in the preparation of $\mathrm{Ru}$ (II) complexes incorporating (bulky) electron-donating alkyl- and arylphosphine pincer ligands, did not yield 4. The transcyclometalation (TCM) reaction is an alternative method for efficient preparation of achiral ${ }^{10}$ and chiral ${ }^{8 b, 11}\left[\mathrm{RuCl}(\mathrm{PCP})\left(\mathrm{PPh}_{3}\right)\right]$ complexes. Exchange of the NCN ligand in the NCN-Ru(II) precursor $2^{12}$ by

(10) Dani, P.; Karlen, T.; Gossage, R. A.; Smeets, W. J. J.; Spek, A. L.; van Koten, G. J. Am. Chem. Soc. 1997, 119, 11317.

(11) Dani, P.; Albrecht, M.; van Klink, G. P. M.; van Koten, G. Organometallics 2000, 19, 4468. the PCP ligand gave complex 4 in good yield (80\%) (Scheme 1), which can be isolated as a remarkably airand water-stable red powder after workup. In general, $\mathrm{PCP}-\mathrm{Ru}(\mathrm{II})$ species are readily oxidized by atmospheric $\mathrm{O}_{2} \cdot{ }^{5}$ Complex 4 can be stored in air over months, and its purification can be conveniently undertaken by column chromatography.

The structure of 4 in solution was assigned using ${ }^{1} \mathrm{H}$, ${ }^{31} \mathrm{P}\left\{{ }^{1} \mathrm{H}\right\},{ }^{13} \mathrm{C}\left\{{ }^{1} \mathrm{H}\right\}$, and ${ }^{19} \mathrm{~F}$ NMR spectroscopy and $2 \mathrm{D}$ NMR techniques $\left({ }^{19} \mathrm{~F}-{ }^{19} \mathrm{~F}\right.$ COSY and ${ }^{1} \mathrm{H}-{ }^{19} \mathrm{~F}$ HOESY). The room-temperature ${ }^{31} \mathrm{P}\left\{{ }^{1} \mathrm{H}\right\}$ NMR spectrum exhibits a doublet at $36.5 \mathrm{ppm}\left({ }^{2} J_{\mathrm{P}-\mathrm{P}}=29 \mathrm{~Hz}\right)$ for the $\mathrm{P}\left(\mathrm{C}_{6} \mathrm{~F}_{5}\right)$ groups and a triplet at $35.4 \mathrm{ppm}\left({ }^{2} J_{\mathrm{P}-\mathrm{P}}=29 \mathrm{~Hz}\right)$ for the $\mathrm{PPh}_{3}$ ligand. This, along with the multiplicity of the ${ }^{1} \mathrm{H}$ NMR signals, is consistent with trans positioning of the $\mathrm{PCP}{ }^{\mathrm{ArF}}$ phosphorus atoms and with the $\mathrm{PPh}_{3}$ ligand cis to the $\mathrm{P}\left(\mathrm{C}_{6} \mathrm{~F}_{5}\right)_{2}$ groups. ${ }^{5,13}$

In the ${ }^{19} \mathrm{~F}$ NMR spectrum, two resonances are found for the para fluorine $(-152.6$ and $-153.3 \mathrm{ppm})$, indicating that the $\mathrm{C}_{6} \mathrm{~F}_{5}$ rings are diastereotopic. These findings suggest that the square-pyramidal $C_{s}$-symmetric arrangement previously observed for the $\mathrm{PCP}-\mathrm{Ru}(\mathrm{II})$ complexes is retained. ${ }^{5,13}$ The doublet for the $\mathrm{P}\left(\mathrm{C}_{6} \mathrm{H}_{5}\right)_{2}$ groups in the protio complex $\mathbf{5}$ falls in the same region $(37.0 \mathrm{ppm})$ as the $\mathrm{P}\left(\mathrm{C}_{6} \mathrm{~F}_{5}\right)_{2}$ groups in $\mathbf{4}$. However, in $\mathbf{4}$ the phosphorus resonance of the $\mathrm{PPh}_{3}$ ligand is considerably upfield compared to the case for its protio analogue 5 (81.0 ppm). This shielding of ca. $50 \mathrm{ppm}$ cannot be exclusively explained on considering the donor characteristics of the phosphorus atoms of the $\mathrm{P}\left(\mathrm{C}_{6} \mathrm{~F}_{5}\right)_{2}$ groups. The signal of $\mathrm{C}_{\text {ipso }}$ in the ${ }^{13} \mathrm{C}\left\{{ }^{1} \mathrm{H}\right\}$ NMR spectrum is also considerably shifted to higher field ( $149.5 \mathrm{ppm}$; $\left.{ }^{2} J_{\mathrm{C}-\mathrm{P}}=10 \mathrm{~Hz}\right)$ in comparison to what was previously

(12) Sutter, J.-P.; James, S. L.; Steenwinkel, P.; Grove, D. M. Veldman, N.; Spek, A. L.; van Koten, G. Organometallics 1996, 15, 941

(13) Dani, P.; van Klink, G. P. M.; van Koten, G. Eur. J. Inorg. Chem. 2001, 7, 1465 . 
observed for 5 (172.5 ppm; $\left.{ }^{2} \boldsymbol{J}_{\mathrm{C}-\mathrm{P}}=20 \mathrm{~Hz}\right) .{ }^{13}$ It can be noted that the much larger ${ }^{2} \boldsymbol{J}_{\mathrm{C}-\mathrm{P}}$ value for $\mathrm{C}_{\mathrm{ipso}}$ in $\mathbf{5}$, in comparison to that in $\mathbf{4}$, is caused by the chloride ligand being positioned trans to $\mathrm{C}_{\text {ipso }}$.

An X-ray crystal structure determination of 4 (Figure 1 , left) revealed that the fluorinated pincer ligand has a profound effect on the metal coordination environment. The molecular structures of $\mathbf{4}$ and its solvent-free protio analogue $\mathbf{5}^{14}$ (Figure 1, right) both show the $\mathrm{Ru}$ (II) center to be in a distorted-square-pyramidal geometry with $\sigma$ parameters ${ }^{15}$ of 0.13 and 0.04 , respectively. Interestingly, the apical position of $\mathbf{4}$ is occupied by the $\mathrm{C}_{\text {ipso }}$ atom of the arene in the PCPArF ligand, whereas in 5 the phosphorus atom of the $\mathrm{PPh}_{3}$ ligand occupies this position. The basal plane of $\mathbf{4}$, formed by P1, P2, $\mathrm{P} 3$, and $\mathrm{Cl} 1$, is a puckered square due to the ring strain of the chelated PCP ligand. In 5 the basal plane is almost planar. A comparison of the distances between $\mathrm{Ru}$ and the $\mathrm{PPh}_{3}$ ligand in $\mathbf{4}$ and $\mathbf{5}$ shows that the $\mathrm{Ru}-\mathrm{P}$ bond is significantly elongated in 4 by $0.1 \AA$, which can be ascribed to the trans influence of the chloride ligand.

In the majority of square-pyramidal five-coordinated metal complexes, the metal atom is located above the basal plane. In $\mathbf{5}$ the $\mathrm{Ru}(\mathrm{II})$ center lies $0.52 \AA$ above this plane. A quite different situation is observed for $\mathbf{4}$, with the $\mathrm{Ru}(\mathrm{II})$ center placed in the basal plane with a deviation of only $0.05 \AA$. Such an arrangement is often found in (pseudo)octahedral complexes. Indeed, in 4 a weak interaction trans to $\mathrm{C} 1$ is found between $\mathrm{Ru} 1$ and $\mathrm{H} 34$ of the $\mathrm{PPh}_{3}$ ligand. The Ru1-H34 distance of 2.86 $\AA$ is shorter than the sum of their contact radii. ${ }^{16}$ This $\mathrm{Ru}-\mathrm{H}$ interaction is also reflected in tilting of the $\mathrm{PPh}_{3}$ ligand with respect to the $\mathrm{Ru}-\mathrm{P}$ bond orientation. The Ru1-P3-C33 angle of $103.38(6)^{\circ}$ is much smaller than the corresponding angles involving C39 and C45 (120.43(6) and $125.24(6)^{\circ}$, respectively). The $\mathrm{Ru}-\mathrm{P}-\mathrm{C}$ angles of the $\mathrm{PPh}_{3}$ ligand in 5 without a $\mathrm{Ru}-\mathrm{H}$ interaction vary much less $\left(113.97(12)-117.20(11)^{\circ}\right)$. Although quite some broadening of the $\mathrm{PPh}_{3}$ peaks is noted in the lowtemperature ${ }^{1} \mathrm{H}$ NMR spectrum, this intramolecular interaction is not explicitly observed in solution.

Fluxional behavior was observed in the ${ }^{19} \mathrm{~F}$ NMR spectrum at room temperature. The signal for the ortho fluorines found as a broad singlet at $-128.77 \mathrm{ppm}$ at room temperature splits into four signals at -124.20 , $-128.32,-130.20$, and $-134.67 \mathrm{ppm}$ on cooling to -40 ${ }^{\circ} \mathrm{C}$. Low-temperature ${ }^{19} \mathrm{~F}-{ }^{19} \mathrm{~F}$ COSY shows that the middle two peaks correlate with one $\mathrm{C}_{6} \mathrm{~F}_{5}$ ring while the outer signals relate to the other. A similar situation is observed with the meta fluorine signals, but the para fluorine signals remain unchanged. As the $\mathrm{C}_{6} \mathrm{~F}_{5}$ rings on each $\mathrm{P}$ atom are diastereotopic, these data imply restricted $\mathrm{P}-\mathrm{C}_{6} \mathrm{~F}_{5}$ rotation; the $\mathrm{C}_{6} \mathrm{~F}_{5}$ group proximal to the $\mathrm{PPh}_{3}$ was assigned by a low-temperature ${ }^{1} \mathrm{H}-{ }^{19} \mathrm{~F}$ HOESY NMR cross-peak between the ortho fluorines at -128.32 with the ortho protons of the $\mathrm{PPh}_{3}$. This fluxional behavior was not observed for $\mathbf{5},{ }^{5 b, 13}$ which is in line with the larger overall steric bulk of $\mathrm{C}_{6} \mathrm{~F}_{5}$ vs $\mathrm{C}_{6} \mathrm{H}_{5}$. Still, the $\mathrm{C}_{\mathrm{ipso}}$ atom of the cyclometalated PCPArF

(14) Lutz, M.; Dani, P.; Spek, A. L.; van Koten, G. Private communication to the Cambridge Crystallographic Database, refcode JUJXOB, 1999

(15) Addison, A. W.; Rao, T. N.; Reedijk, J.; van Rijn, J.; Verschoor, G. C. J. Chem. Soc., Dalton Trans. 1984, 1349

(16) Bondi, A. J. Phys. Chem. 1964, 68, 441.
Table 1. Absorption and Electrochemical Data for Complexes 4 and 5

\begin{tabular}{cccc}
\hline compd & $\begin{array}{c}\lambda_{\max }^{a, b} \\
\mathrm{~nm}\end{array}$ & $\begin{array}{c}\epsilon_{\max }^{a, b} / 10^{3} \mathrm{dm}^{3} \\
\mathrm{~mol}^{-1} \mathrm{~cm}^{-1}\end{array}$ & $\begin{array}{c}E_{1 / 2}(\mathrm{Ru}(\mathrm{II}) / \\
\mathrm{Ru}(\mathrm{III}))^{a, c} / \mathrm{V}\end{array}$ \\
\hline $\mathbf{4}$ & 523 & 1.22 & 0.39 \\
$\mathbf{5}$ & 630 & 1.25 & -0.01
\end{tabular}

${ }^{a}$ Measured in $\mathrm{CH}_{2} \mathrm{Cl}_{2}$ at $298 \mathrm{~K} .{ }^{b}$ Absorption maxima and absorption molar coefficients of bands in the visible spectral region. ${ }^{c}$ Redox potentials $\left(E_{1 / 2}\right)$ in $\mathrm{V}$ vs $\mathrm{Fc} / \mathrm{Fc}^{+}$.

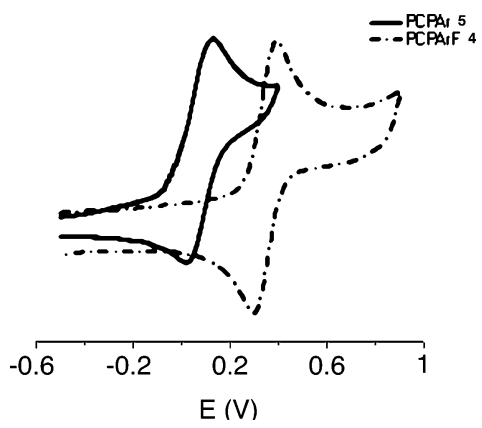

Figure 2. Cyclic voltammograms of complexes 4 and 5 measured in $\mathrm{CH}_{2} \mathrm{Cl}_{2}$ at $298 \mathrm{~K}(0.1 \mathrm{M}$ TBAH; scan rate 100 $\left.\mathrm{mV} \mathrm{s}^{-1}\right)$.

ligand in 4 takes the apical position rather than $\mathrm{PPh}_{3}$ taking this position, as previously postulated. ${ }^{5}$

DFT calculations confirm that the calculated geometry of complex 4 compares favorably to the experimentally determined crystal structure. However, at this point, it is difficult to state whether the stability of this configuration is mainly due to the electronic influence of the $\mathrm{P}\left(\mathrm{C}_{6} \mathrm{~F}_{5}\right)$ or is due to steric reasons.

Electrochemical studies and electronic absorption spectra show that the redox and spectroscopic properties of 4 change considerably compared to those of $\mathbf{5}$, due to the presence of the strongly electron withdrawing fluorinated groups at the donor phosphorus atoms (see Table 1). The cyclic voltammograms of $\mathbf{4}$ and its protio analogue 5 (Figure 2), measured in $\mathrm{CH}_{2} \mathrm{Cl}_{2}$, exhibit a single reversible one-electron wave corresponding to the $\mathrm{Ru}(\mathrm{II}) / \mathrm{Ru}(\mathrm{III})$ couple. The current for both peaks is linearly dependent on $v^{1 / 2}$ for the scan rates studied (0.05-1 $\left.\mathrm{V} \mathrm{s}^{-1}\right)$, indicating completely reversible, diffusion-controlled processes. As expected, the profound stabilization of the $\mathrm{Ru} d(\pi)$-based orbitals in 4 by $\pi$-accepting $\mathrm{P}\left(\mathrm{C}_{6} \mathrm{~F}_{5}\right)$ groups accounts for the drastic positive shift in the $\mathrm{Ru}(\mathrm{II}) / \mathrm{Ru}$ (III) redox couple (Table 1). These findings correlate with the electronic spectra (Table 1). The UV regions of the spectra of the red complex 4 and green complex 5 exhibit at wavelengths below $350 \mathrm{~nm}$ intense ligand-centered (LC) $\pi \rightarrow \mathrm{p}^{*}$ electronic transitions. In the visible region, broad, much less intense absorptions at 523 and $630 \mathrm{~nm}$ for 4 and $\mathbf{5},{ }^{5 a}$ respectively, are observed. Interestingly, the energies of these bands increase in the order $\mathbf{5}<\mathbf{4}$, suggesting that their position is strongly sensitive to the varied $\pi$-acceptor properties of the substituents on the phosphorus. The assignments of the lowest energy absorption bands have been based on the ground-state DFT calculations on complexes 4 and 5. A threedimensional plot of the HOMOs and LUMOs of $\mathbf{4}$ and $\mathbf{5}$ is depicted in Figure 3. The HOMOs of $4(-5.62 \mathrm{eV})$ and $5(-4.72 \mathrm{eV})$ are predominantly metalin character. The higher energy of the HOMO of $\mathbf{5}(\Delta E=0.90 \mathrm{eV})$ is 


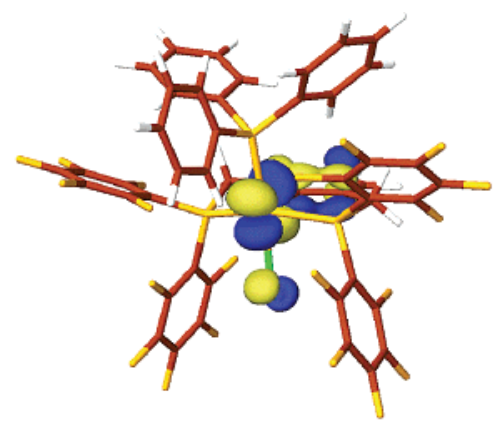

(4) $\mathrm{HOMO}(-5.62 \mathrm{eV})$

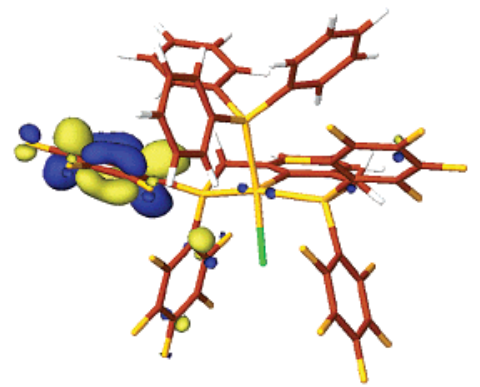

(4) LUMO (-2.44 eV)

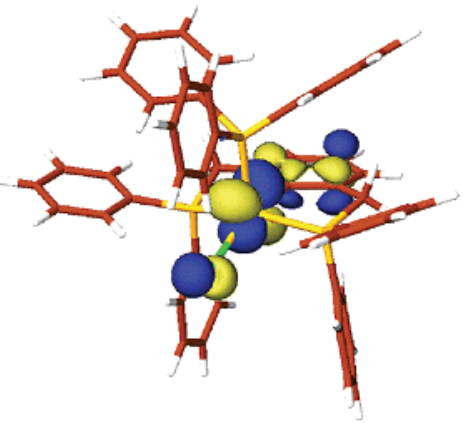

(5) $\mathrm{HOMO}(-4.72 \mathrm{eV})$

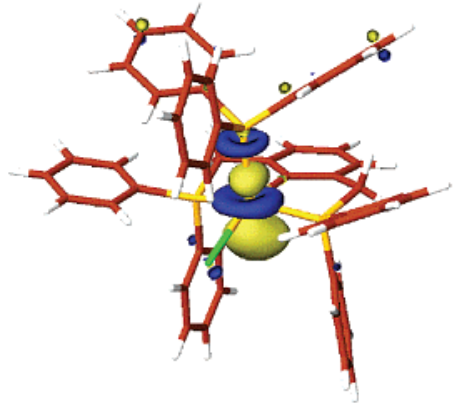

(5) LUMO (-1.76 eV)

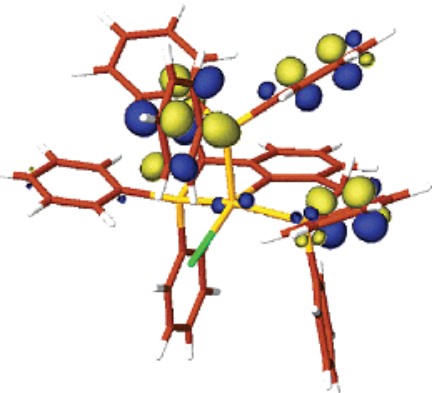

(5) LUMO + $1(-0.81 \mathrm{eV})$

Figure 3. Contour plots of the HOMO and LUMO of 4 (top) and the HOMO, LUMO and LUMO +1 of $\mathbf{5}$ (bottom) calculated at the B3LYP/LANL2-DZ level.

consistent with the results obtained by the electrochemical studies, which reveal that $\mathbf{5}$ is more prone to oxidation than 4. The LUMO of $4(-2.44 \mathrm{eV})$ is substantially delocalized over the PCPArF ligand, suggesting that the most intense transition in the visible region centered at $523 \mathrm{~nm}$ posseses a significant metal-toligand-charge-transfer (MLCT) character. However, the LUMO of $5(-1.76 \mathrm{eV})$ is clearly different and posseses a strong d-metal character. Thus, it is tempting to assign the lowest energy transition of $\mathbf{5}$ centered at 630 $\mathrm{nm}$ as $\mathrm{d}-\mathrm{d}$ in nature. However, it cannot be excluded that MLCT transitions occurring from the HOMO to other unoccupied molecular orbitals localized on the ligands, such as the LUMO +1 (Figure 3), contribute to the observed band. Calculations on $\mathbf{4}$ and $\mathbf{5}$ are ongoing in order to assign all the bands observed in the recorded electronic spectra.

In conclusion, the present studies demonstrate that $\mathrm{C}_{6} \mathrm{~F}_{5}$ groups directly bound to the phosphorus centers of PCP pincer ligands have a positive effect on the stability of the metal ion and alter considerably the structure and the electronic properties of 4. This may be helpful for an understanding of the high stability of the obtained configuration for 4. DFT calculations show that the introduction of electron-withdrawing groups on the phosphorus atoms of PCP pincer ligands importantly change the character of the frontier orbitals in 4. Work in progress is directed toward a detailed understanding of the reactivity of $\mathbf{4}$ in both substitution reactions and catalysis. Preliminary results suggest that the remarkable stability and uncommon structural features of 4, as presented here, significantly affect its behavior in hydrogen transfer catalysis.

\section{Experimental Section}

General Procedures. All reactions were performed under an atmosphere of dry oxygen-free nitrogen using Schlenk techniques or in a nitrogen-filled MBraun 150 G1 glovebox. Pentane and toluene were dried over $\mathrm{Na}$ sand, THF and diethyl ether were dried over $\mathrm{Na}$ /benzophenone, and $\mathrm{CH}_{2} \mathrm{Cl}_{2}$ was dried over $\mathrm{CaH}_{2}$. All solvents were freshly distilled under nitrogen prior to use. $\mathrm{CD}_{2} \mathrm{Cl}_{2}$ was purchased from Cambridge Isotope Laboratories, dried over $\mathrm{CaH}_{2}$, distilled prior to use, and stored in a Schlenk flask over $4 \AA$ molecular sieves under nitrogen. 1D NMR spectra $\left({ }^{1} \mathrm{H}(300.1 \mathrm{MHz}),{ }^{13} \mathrm{C}(75.5 \mathrm{MHz})\right.$, ${ }^{19} \mathrm{~F}(282.4 \mathrm{MHz})$, and $\left.{ }^{31} \mathrm{P}(121.4 \mathrm{MHz})\right)$ and $2 \mathrm{D}{ }^{19} \mathrm{~F}-{ }^{19} \mathrm{~F}-\mathrm{COSY}$ experiments were recorded on a Varian Inova $300 \mathrm{MHz}$ spectrometer. 2D NMR ${ }^{1} \mathrm{H}-{ }^{19} \mathrm{~F}$-HOESY experiments were performed using a Bruker AMX $300 \mathrm{MHz}$ instrument (chemical shift values are reported in $\mathrm{ppm}(\delta)$ and referenced internally to residual solvent signals $\left({ }^{1} \mathrm{H},{ }^{13} \mathrm{C}\right)$ or externally ${ }^{(19} \mathrm{F}, \mathrm{C}_{6} \mathrm{~F}_{6}, \delta-164.9 ;{ }^{31} \mathrm{P}, \mathrm{H}_{3} \mathrm{PO}_{4}$ in $\left.\mathrm{D}_{2} \mathrm{O}, \delta 0\right)$. All reagents were purchased from Acros Chemicals and used as received. Ligand $\mathbf{1}^{6}$ and complex $\mathbf{2}^{12}$ were synthesized via literature procedures. Elemental analyses were performed by Dornis und Kolbe, Mikroanalytisches Laboratorium, Mülheim a. d. Ruhr, Germany.

Cyclic Voltammetry Experiments. The electrochemical experiments were performed with an EG\&G Model 263A potentiostat/galvanostat controlled by a Model 270/250 Research Electrochemistry Software (version 4.23). A threeelectrode system was used, consisting of a platinum $(\mathrm{Pt})$ working electrode, a platinum (Pt) auxiliary electrode, and a $\mathrm{Ag} / \mathrm{AgCl}$ reference electrode separated from the test solution by a glass frit. The experiments were carried out in $\mathrm{CH}_{2} \mathrm{Cl}_{2}$ at room temperature under a nitrogen atmosphere with tetrabutylammonium hexafluorophosphate (TBAH) as electrolyte $(0.1$ M). All potentials are reported relative to SCE. Linear voltammograms were obtained at a scan rate of $100 \mathrm{mV} \mathrm{s}^{-1}$.

Electronic Spectroscopic Measurements. UV-vis absorption spectra were obtained on a Varian Cary 1 spectrophotometer using matched $1 \mathrm{~cm}$ cells and operating with 0.5 
$\mathrm{nm}$ spectral resolution. Peak positions are given with an 0.5 $\mathrm{nm}$ accuracy.

Computational Details. The geometries of $\mathbf{4}$ and $\mathbf{5}$ were optimized at the B3LYP/LANL2-DZ level ${ }^{17}$ using GAMESSUK. ${ }^{18}$ Basis sets were obtained from the Extensible Computational Chemistry Environment Basis Set Database, Version 02/25/04, as developed and distributed by the Molecular Science Laboratory, which is part of the Pacific Northwest Laboratory, P.O. Box 999, Richland, WA 99352, and funded by the U.S. Department of Energy.

Crystal Structure Determination of 4. Crystal data are as follows: $\mathrm{C}_{50} \mathrm{H}_{22} \mathrm{ClF}_{20} \mathrm{P}_{3} \mathrm{Ru}$, $\mathrm{fw}=1232.11$, dark purple needle, $0.48 \times 0.06 \times 0.06 \mathrm{~mm}^{3}$, triclinic, $P \overline{1}$ (No. 2), $a=12.1513(1)$ $\AA, b=14.5284(1) \AA, c=15.7986(1) \AA, \alpha=101.9208(3)^{\circ}, \beta=$ $106.6401(3)^{\circ}, \gamma=112.0818(3)^{\circ}, V=2315.99(3) \AA^{3}, Z=2, \rho=$ $1.767 \mathrm{~g} / \mathrm{cm}^{3}$. A total of 78348 reflections up to a resolution of $((\sin \theta) / \lambda)_{\max }=0.65 \AA^{-1}$ were measured on a Nonius KappaCCD diffractometer with a rotating anode and graphite monochromator $(\lambda=0.71073 \AA)$ at a temperature of $150(2)$ $\mathrm{K}$. An absorption correction based on multiple measured reflections was applied $\left(\mu=0.619 \mathrm{~mm}^{-1}, 0.72-0.96\right.$ correction range). A total of 10602 reflections were unique $\left(R_{\text {int }}=0.0385\right)$. The structure was solved with direct methods ${ }^{19}$ and refined with SHELXL-9720 on $F^{2}$ values of all reflections. Nonhydrogen atoms were refined with anisotropic displacement parameters. All hydrogen atoms were located in the difference Fourier map and refined as rigid groups. A total of 676 parameters were refined with no restraints. R1/wR2 $(I>2 \sigma$ (I)): $0.0262 / 0.0594 . \mathrm{R} 1 / \mathrm{wR} 2$ (all reflections): $0.0344 / 0.0627 . S$ $=1.038$. The residual electron density was between -0.47 and $0.40 \mathrm{e} / \AA^{3}$. Geometry calculations, drawings, and checking for higher symmetry were performed with the PLATON ${ }^{21}$ package.

(17) (a) Dunning, T. H., Jr.; Hay, P. J. In Modern Theoretical Chemistry; Schaefer, H. F., III, Ed.; Plenum Press: 1977; Vol. 3. (b) Wadt, W. R.; Hay, P. J. J. Chem. Phys. 1985, 82, 284. (c) Hay, P. J.; Wadt, W. R. J. Chem. Phys. 1985, 82, 299.

(18) Guest, M. F.; Bush, L. J.; van Dam, H. J.; Sherwood, P.; Thomas, J. M. H.; van Lenthe, J. H.; Havenith, R. W. A.; Kendrick, J. J. Mol. Phys. 2005, 103, 719

(19) Altomare, A.; Burla, M. C.; Camalli, M.; Cascarano, G. L.; Giacovazzo, C.; Guagliardi, A.; Moliterni, A. G. G.; Polidori, G.; Spagna, R. J. Appl. Crystallogr. 1999, 32, 115.

(20) Sheldrick, G. M. SHELXL-97: Program for Crystal Structure Refinement; Universität Göttingen, Göttingen, Germany, 1997.

(21) Spek, A. L. J. Appl. Crystallogr. 2003, 36, 7.
$\left[\operatorname{RuCl}\left\{\mathbf{C}_{6} \mathbf{H}_{3}\left(\mathbf{C H}_{2} \mathbf{P}\left(\mathbf{C}_{6} \mathbf{F}_{5}\right)_{2}\right)_{2}-\mathbf{2 , 6}\right\}\left(\mathbf{P P h}_{3}\right)\right]$ (4). Ligand $\mathbf{1}(0.170$ g; $0.2 \mathrm{mmol})$ was dissolved in dry benzene $(5 \mathrm{~mL})$ and transferred, at room temperature, into a Schlenk flask containing $2(0.12 \mathrm{~g} ; 0.2 \mathrm{mmol})$ in $10 \mathrm{~mL}$ of dry benzene. The purple reaction mixture turned to deep red after $3 \mathrm{~h}$ upon heating. After $14 \mathrm{~h}$ of heating under reflux, the solvent was removed under vacuum. The obtained red residue was washed with hexane until no more free $m$-bis(amino)aryl ligand $\mathbf{3}$ could be detected by ${ }^{1} \mathrm{H}$ NMR spectroscopy and dried under vacuum. Yield: $0.209 \mathrm{~g}(83 \%) .{ }^{1} \mathrm{H}$ NMR $\left(\mathrm{CD}_{2} \mathrm{Cl}_{2}\right): \delta 3.90\left(\mathrm{bd},{ }^{2} J_{\mathrm{H}-\mathrm{H}}=\right.$ $\left.16 \mathrm{~Hz}, 2 \mathrm{H}, \mathrm{CH}_{2}\right), 4.16\left(\mathrm{bd},{ }^{2} J_{\mathrm{H}-\mathrm{H}}=16 \mathrm{~Hz}, 2 \mathrm{H}, \mathrm{CH}_{2}\right), 6.77(\mathrm{t}$, $\left.{ }^{3} J_{\mathrm{H}-\mathrm{H}}=8.5 \mathrm{~Hz}, 6 \mathrm{H}, o-\mathrm{H} \mathrm{PPh}_{3}\right), 6.90\left(\mathrm{t},{ }^{3} J_{\mathrm{H}-\mathrm{H}}=7.3 \mathrm{~Hz}, 1 \mathrm{H}\right.$, $\mathrm{Ar}), 7.00\left(\mathrm{~d},{ }^{3} J_{\mathrm{H}-\mathrm{H}}=7.3 \mathrm{~Hz}, 2 \mathrm{H}, \mathrm{Ar}\right), 7.12\left(\mathrm{t},{ }^{3} J_{\mathrm{H}-\mathrm{H}}=7.0 \mathrm{~Hz}\right.$, $\left.6 \mathrm{H}, m-\mathrm{H} \mathrm{PPh})_{3}\right), 7.31\left(\mathrm{t},{ }^{3} J_{\mathrm{H}-\mathrm{H}}=7.3 \mathrm{~Hz}, 3 \mathrm{H}, p-\mathrm{H} \mathrm{PPh}_{3}\right) .{ }^{13} \mathrm{C}$ $\operatorname{NMR}\left(\mathrm{CD}_{2} \mathrm{Cl}_{2}\right): \delta 38.5\left(\mathrm{~m}, \mathrm{CH}_{2}\right), 107.6\left(\mathrm{~m}, \mathrm{C}_{\text {quat }} \mathrm{Ar}^{\mathrm{F}}\right), 122.8(\mathrm{~s}$, $\mathrm{Ar}), 123.6$ (vt, Ar), $128.0\left(\mathrm{~d},{ }^{3} J_{\mathrm{C}-\mathrm{P}}=9 \mathrm{~Hz}, m-\mathrm{C} \mathrm{PPh}\right.$ ), 130.4 $\left(\mathrm{s}, p-\mathrm{C} \mathrm{PPh}_{3}\right), 133.3\left(\mathrm{~d},{ }^{2} J_{\mathrm{C}-\mathrm{P}}=9 \mathrm{~Hz}, o-\mathrm{C} \mathrm{PPh}\right), 135.1\left(\mathrm{~d},{ }^{1} J_{\mathrm{C}-\mathrm{P}}\right.$ $=39 \mathrm{~Hz}, \mathrm{C}_{\text {quat }} \mathrm{PPh}_{3}$ ), 137.1 (doublet of multiplet, ${ }^{1} J_{\mathrm{C}-\mathrm{F}}=312.4$ $\mathrm{Hz}, \mathrm{Ar}^{\mathrm{F}}$ ), 142.8 (doublet of multiplet, ${ }^{1} J_{\mathrm{C}-\mathrm{F}}=256.3 \mathrm{~Hz}, \mathrm{Ar}^{\mathrm{F}}$ ), $146.3\left(\mathrm{t}, \mathrm{Ar}\right.$ ), 147.3 (doublet of multiplet, ${ }^{1} J_{\mathrm{C}-\mathrm{F}}=247.5 \mathrm{~Hz}$, $\left.\mathrm{Ar}^{\mathrm{F}}\right), 149.5\left(\mathrm{~d},{ }^{2} J_{\mathrm{C}-\mathrm{P}}=10 \mathrm{~Hz}, \mathrm{C}_{\mathrm{ipso}}, \mathrm{Ar}\right) .{ }^{31} \mathrm{P} \mathrm{NMR}\left(\mathrm{CD}_{2} \mathrm{Cl}_{2}\right) \delta$ : $35.4\left(\mathrm{t},{ }^{2} J_{\mathrm{P}-\mathrm{P}}=29 \mathrm{~Hz}, \mathrm{PPh}_{3}\right), 36.5\left(\mathrm{~d},{ }^{2} J_{\mathrm{P}-\mathrm{P}}=29 \mathrm{~Hz}, \mathrm{P}\left(\mathrm{C}_{6} \mathrm{~F}_{5}\right)_{2}\right)$, ${ }^{19} \mathrm{~F}$ NMR $\left(\mathrm{CD}_{2} \mathrm{Cl}_{2}\right.$, room temperature): $\delta-164.28(\mathrm{bs}, 4 \mathrm{~F}, m-\mathrm{F}$ $\left.\left(\mathrm{C}_{6} \mathrm{~F}_{5}\right)\right),-163.56\left(\mathrm{bs}, 4 \mathrm{~F}, m-\mathrm{F}\left(\mathrm{C}_{6} \mathrm{~F}_{5}\right)\right),-153.30\left(\mathrm{t},{ }^{3} \boldsymbol{J}_{\mathrm{F}-\mathrm{F}}=20\right.$ $\left.\mathrm{Hz}, 2 \mathrm{~F}, p-\mathrm{F}\left(\mathrm{C}_{6} \mathrm{~F}_{5}\right)\right),-152.60\left(\mathrm{t},{ }^{3} J_{\mathrm{F}-\mathrm{F}}=20 \mathrm{~Hz}, 2 \mathrm{~F}, p-\mathrm{F}\left(\mathrm{C}_{6} \mathrm{~F}_{5}\right)\right)$, $-128,7$ (bs, o-F $\left(\mathrm{C}_{6} \mathrm{~F}_{5}\right)$ ). Anal. Calcd for $\mathrm{C}_{50} \mathrm{H}_{22} \mathrm{ClF}_{20} \mathrm{P}_{3} \mathrm{Ru}$ : C, 48.74; H, 1.80; P, 7.54. Found: C, 48.56; H, 1.77; P, 7.46.

Acknowledgment. We thank Mrs. Qiao Wu and Mr. Darryl Morrison of the University of Calgary for performing the HOESY measurements and NWO/NCF for use of the supercomputer time on TERAS/ASTER, SARA (The Netherlands, Project No. SG-032). This work was supported by the Council for Chemical Sciences from the Dutch Organization of Scientific Research (NWO) and Natural Sciences and Engineering Research Council (NSERC) of Canada (P.A.C.). R.W.A.H. acknowledges financial support from NWO Grant No. 700.53.401.

Supporting Information Available: CIF file giving X-ray structural data for complex 4. This material is available free of charge via the Internet at http://pubs.acs.org.

OM050422N 